\begin{tabular}{|l|l|l||}
\hline \multicolumn{2}{|c|}{ PublisherInfo } \\
\hline \hline PublisherName & $:$ & Palgrave Macmillan UK \\
\hline \hline PublisherLocation & $:$ & London \\
\hline \hline PublisherImprintName & $:$ & Palgrave Macmillan \\
\hline \hline
\end{tabular}

\title{
Services producer price index (experimental) - second quarter 2007
}

\begin{tabular}{|l|l|l||}
\hline \multicolumn{2}{|c|}{ ArticleInfo } \\
\hline \hline ArticleDOI & $:$ & $10.1057 /$ palgrave.elmr.1410158 \\
\hline \hline ArticleCategory & $:$ & Feature \\
\hline \hline ArticleFirstPage & $:$ & 53 \\
\hline \hline ArticleLastPage & $:$ & 54 \\
\hline \hline & & RegistrationDate $:$ 2007-10-19 \\
ArticleHistory & $:$ & OnlineDate $\quad: 2007-10-19$ \\
\hline \hline ArticleCopyright & $:$ & Crown copyright2007 \\
\hline \hline
\end{tabular}


Ian Richardson, Aff1

\section{Illustrates the effects some industries are having on the aggregate indicator measuring movements in prices charged for services.}

The experimental services producer price index (SPPI) measures movements in prices charged for services supplied by businesses to other businesses, local and national government. This article shows the effects some industries are having on the top-level SPPI. It continues the quarterly feature previously published in Economic Trends. The data produced are used internally by the Office for National Statistics as a deflator for the index of services and the quarterly measurement of gross domestic product. The index is also used by HM Treasury and the Bank of England to help monitor inflation in the economy.

The Full Text of this article can be found on the National Statistics website (http://www.statistics.gov.uk/elmr/10_07/downloads/elmr_oct07_richardson.pdf). 